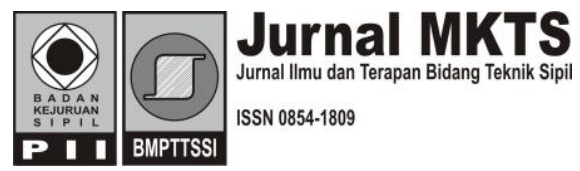

\title{
Studi Eksperimental Kekuatan dan Perilaku Sambungan Kolom pada Struktur DfD (Design for Disassembly)
}

\author{
Intan Fitriani \\ Magister Teknik Sipil Fakultas Teknik Universitas Diponegoro \\ J1. Prof. H. Soedarto, SH, Tembalang, Semarang \\ E-mail: intanfitriani2@gmail.com \\ Sukamta \\ Jurusan Teknik Sipil Fakultas Teknik Universitas Diponegoro \\ Jl. Prof. H. Soedarto, SH, Tembalang, Semarang \\ E-mail: kamt_id@yahoo.com \\ Ilham Nurhuda \\ Jurusan Teknik Sipil Fakultas Teknik Universitas Diponegoro \\ Jl. Prof. H. Soedarto, SH, Tembalang \\ E-mail: ilham@undip.ac.id
}

\begin{abstract}
DfD building system is a new approach in construction. Using DfD building system can reduce construction waste and reuse building components. This research examines the strength and behaviour of DfD column connections. Two types column connections were studied.The first connection employed $H$ shaped steel elements bolted to the column while the second connection was bolt and plate connection. The behavior of columns with connections was compared to that of without connection. This study was carried out to investigate the strength, crack patterns, and failure mechanisms of precast concrete with dry joint on DfD column structure. All specimens were subject to normal force applied with an eccentricity of $67 \mathrm{~mm}$. The test results indicate that both columns with connections were able to withstand design loads. This study also confirmed that the shear strength calculation of corbel based on SNI 03-2847-2002 section 13.9 was conservative to use as the value was still smaller than that obtained from this experiment.
\end{abstract}

Keywords: Design for diassembly, Precast concrete, Corbel.

\begin{abstract}
Abstrak
Sistem bangunan DfD merupakan pendekatan baru dalam konstruksi untuk meningkatkan penggunaan material dan komponen bangunan yang dapat digunakan kembali. Pada penelitian ini, dilakukan pengujian kolom-kolom beton pracetak dengan sambungan kering untuk digunakan pada struktur DfD. Sambungan kolom yang diteliti adalah sambungan dengan menggunakan profil dan sambungan dengan menggunakan baut dan plat. Perilaku kolom dengan sambungan dibandingkan dengan perilaku kolom tanpa sambungan. Penelitian ini dilakukan untuk menyelidiki kekuatan, pola retak, dan mekanisme kegagalan yang terjadi pada beton pracetak dengan sambungan kering pada struktur kolom DfD. Pengujian laboratorium dilakukan dengan membebani eksentrisitas $67 \mathrm{~mm}$. Hasil pengujian menunjukkan bahwa kolom yang diuji dapat menahan beban desain rencana, sehingga dapt diaplikasikan pada bangunan rumah/ruko bertingkat dua atau tiga lantai dengan jarak kolom maksimum 4 meter. Pada penelitian ini, retak awal terjadi di daerah tarik kolom kemudian terjadi retak di corbel ketika kolom dibebani mendekati beban maksimum. Penelitian ini juga menunjukkan bahwa perhitungan kuat geser korbel berdasarkan SNI 03-2847-2002 pasal 13.9 cukup aman digunakan karena masih lebih kecil dari kuat geser pengujian.
\end{abstract}

Kata-kata Kunci: Design for diassembly, Beton pracetak, Corbel. 


\section{Pendahuluan}

Kecepatan pelaksanaan bangunan sipil saat ini sangat dibutuhkan terutama di kota-kota besar. Bentuk bangunan dan desain denah yang sudah ada seringkali berubah mengikuti kebutuhan dan selera pemilik sejalan dengan perubahan waktu. Perubahan bentuk dan desain pada struktur konvensional membutuhkan biaya yang tinggi.

Penggunaan beton pracetak dengan sambungan kering diharapkan dapat menjadi solusi. Apabila bentuk struktur dengan beton pracetak akan diubah, beton pracetak yang lama masih dapat digunakan karena mudah dibongkar pasang.

Kemampuan beton pracetak untuk menggantikan beton monolit masih perlu diteliti lebih lanjut. Pada penelitian ini, dilakukan pengujian kolomkolom beton pracetak dengan sambungan kering (dry joint) dan kolom monolit untuk mengetahui kekuatan kolom pracetak dibandingkan dengan kolom monolit. Sambungan dilakukan pada kolom karena dalam pelaksanaannya, kolom pracetak dibagi menjadi beberapa bagian untuk memudahkan dalam transportasi.

Penelitian ini dilakukan dengan tujuan menyelidiki kekuatan beton pracetak dengan sambungan kering pada kolom DfD serta mempelajari pola retak dan mekanisme kegagalan yang terjadi pada beton. Tipe sambungan yang digunakan dalam penelitian ini adalah dry joint dengan menggunakan kombinasi plat dan profil baja serta baut mur. Mutu beton direncanakan $30 \mathrm{MPa}$. Penelitian ini hanya dilakukan pada sambungan kolom DfD yang mengalami pembebanan aksial dan momen lentur satu arah. Kolom DfD ini direncanakan akan diaplikasikan untuk bangunan tempat tinggal atau ruko sederhana.

Jenis sambungan antara komponen beton pracetak yang biasa digunakan dapat dikategorikan menjadi 2 kelompok (Wahyudi et al., 2010), yaitu sambungan kering (dry connection) dan sambungan basah (wet connection). Sambungan kering adalah sambungan antar komponen beton pracetak menggunakan plat besi sebagai penghubung, yang kemudian dilas atau dibaut, sedangkan sambungan basah adalah sambungan antar beton pracetak yang ditandai dengan keluarnya besi tulangan dari beton pracetak. Besi tulangan ini dihubungkan dengan besi tulangan dari beton pracetak yang akan disambungkan dengan cara dicor di tempat. Jenis sambungan ini dapat berfungsi baik untuk mengurangi penambahan tegangan yang terjadi akibat rangkak, susut dan perubahan temperatur. Sambungan basah ini sangat dianjurkan untuk bangunan di daerah rawan gempa karena dapat menjadikan masingmasing komponen beton pracetak menjadi monolit.

Wibowo (2011) melakukan penelitian beton pracetak dengan sambungan kering menggunakan kombinasi plat baja, angker, dan baut. Penelitian dilakukan pada balok dan kolom. Potongan memanjang sambungan balok pracetak dapat dilihat pada Gambar 1. Benda uji balok diuji secara lentur, sedangkan benda uji balok-kolom dan kolom-pondasi diuji siklik.

Pada pengujian balok-kolom, sambungan terletak pada $2 \mathrm{~h}$ balok dari tepi dalam kolom. Pada pengujian kolom-pondasi, sambungan terletak pada $2 \mathrm{~h}$ kolom dari kaki kolom. $\mathrm{H}$ adalah tinggi penampang dari balok atau kolom.

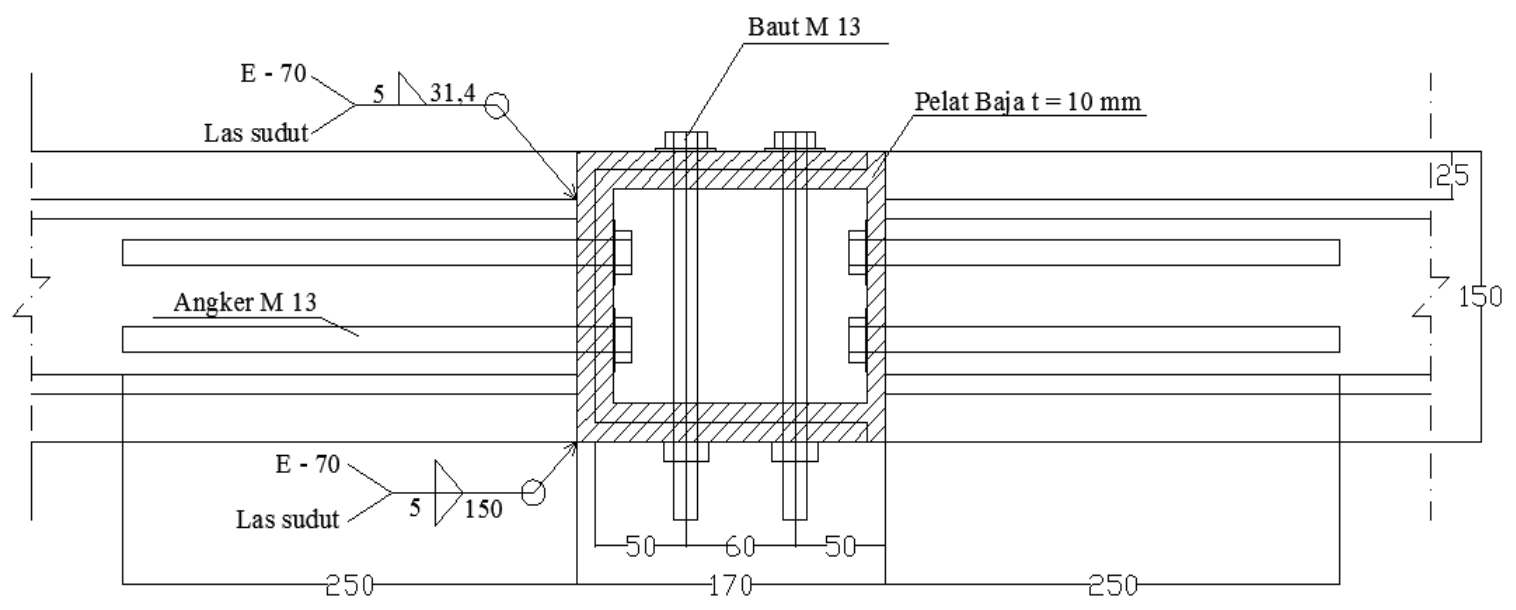

Gambar 1. Potongan memanjang sambungan balok pracetak 
Hasil uji lentur benda uji balok didapat hasil yang memuaskan untuk nilai daktilitasnya. Pada uji beban siklik sambungan balok, sambungan pracetak pada balok berperilaku sangat daktail. Daktilitas yang dihasilkan adalah daktilitas penuh. Uji beban siklik pada sambungan kolom, nilai daktilitas yang dihasilkan sangat baik. Daktilitas yang dihasilkan adalah daktilitas parsial.

Suherman (2011) melakukan penelitian sambungan menggunakan block set connection (BSC). BSC dirancang menggunakan material baja sama dengan benda yang disambung. Benda yang disambung adalah baja tulangan pada beton pracetak. BSC terdiri dari dua buah blok yang dirangkai dalam satu set sambungan dengan jumlah total blok bergantung dari jumlah tulangan yang akan disambung. BSC ini dipasang pada daerah sendi plastis untuk struktur kantilever.

Disipasi energi dari sambungan menggunakan BSC adalah baik dengan harga redaman pada kondisi elastis 4,8\% dan pada daerah inelastis $9,12 \%$. Nilai rata-rata daktilitas konstruksi $\mu=$ 6,45 . Nilai daktilitas ini mempunyai arti bahwa konstruksi sangat daktail dan dapat digunakan untuk perhitungan full ductile yang mensyaratkan nilai daktilitas $\mu=5,3$.

Konstruksi dinyatakan memiliki kekuatan menahan beban. Penurunan kekuatan pada setiap penambahan beban siklik tidak melebihi $20 \%$. Nilai rata-rata faktor kekakuan konstruksi mencapai 0,95. Nilai ini berarti alat sambung BSC memiliki kekakuan sama dengan konstruksi monolit. Pola runtuh konstruksi beton precast menggunakan alat sambung $B S C$ memiliki kesamaan dengan pola runtuh beton monolit. Hal ini berarti memenuhi syarat konstruksi.

Niken (2008) melakukan penelitian terhadap sambungan pracetak menggunakan sambungan model takik. Sambungan yang ditinjau adalah sambungan pada balok dengan lokasi sambungan di tengah bentang. Benda uji balok diuji secara lentur.

Hasil pengujian adalah beban leleh pada batas sambungan dan tengah sambungan tidak mempunyai perbedaan yang berarti. Retak yang terjadi adalah retak lentur kemudian berkembang menjadi retak miring. Sistem sambungan ini mempunyai perilaku lentur seperti struktur monolit, tetapi disarankan dilakukan peninjauan terhadap mekanisme geser.

Review literatur dari penelitian yang sudah ada menunjukkan kemampuan yang baik dari beton pracetak dalam menahan momen lentur yang terjadi. Kemampuan sambungan beton pracetak dalam menahan beban aksial belum banyak diteliti. Oleh karena itu, dalam penelitian ini dilakukan pengujian beton pracetak dengan sambungan.

\section{Metodologi Penelitian}

Beton dan baja yang digunakan sebagai material pembuatan kolom diuji terlebih dahulu. Beton yang digunakan dalam penelitian ini adalah beton readymix dari PT. Jati Kencana Beton. Beton ini kemudian diuji tekan dalam bentuk silinder beton dengan diameter $15 \mathrm{~cm}$ dan tinggi $30 \mathrm{~cm}$. Benda uji silinder beton direncanakan berjumlah 12 buah yang diuji pada umur 14 hari dan pada saat pengujian untuk mengetahui kesesuaian mutu beton dengan rencana.

Pengujian kuat tarik baja dilakukan untuk mengetahui mutu dari baja yang digunakan dalam penelitian. Baja yang diuji tarik adalah baja tulangan, $\mathrm{H}$ beam yang digunakan pada sambungan, plat, dan baut. Pengujian ini dilakukan di Laboratorium Bahan dan Konstruksi Teknik Sipil Universitas Diponegoro.

\section{Dimensi penulangan dan sambungan kolom uji}

Dimensi kolom yang digunakan adalah 150 x 150 mm. Tulangan utama kolom menggunakan 4 tulangan ulir diameter $10 \mathrm{~mm}$ dan tulangan gesernya menggunakan tulangan polos diameter 6 $\mathrm{mm}$ yang dipasang pada jarak setiap $50 \mathrm{~mm}$. Tinggi kolom dibuat $1500 \mathrm{~mm}$ dengan detail penampang kolom seperti pada Gambar 2.

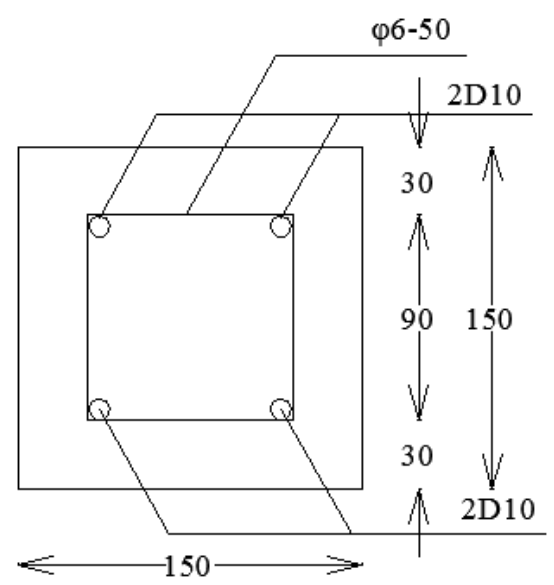

Gambar 2. Detail penampang kolom

Penelitian dilakukan terhadap tiga kolom uji, yaitu satu kolom tanpa sambungan dan dua kolom dengan sambungan. Sambungan yang digunakan yaitu sambungan profil dan sambungan plat. Posisi sambungan dapat dilihat pada Gambar 3, sedangkan detail sambungan dapat dilihat pada Gambar 4 dan Tabel 1. 


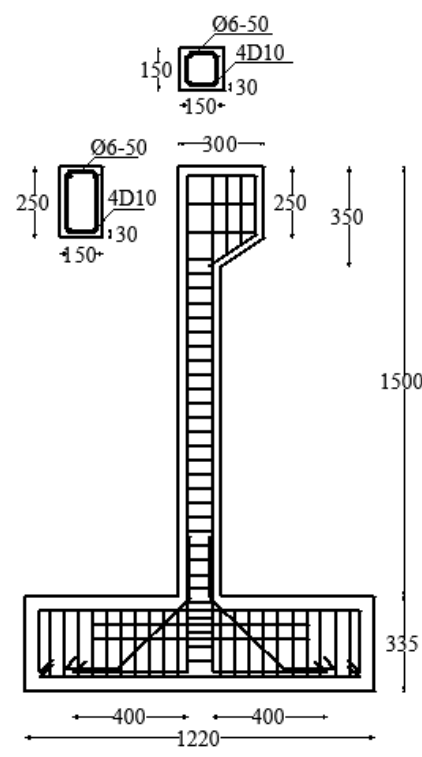

a) kolom tanpa sambungan

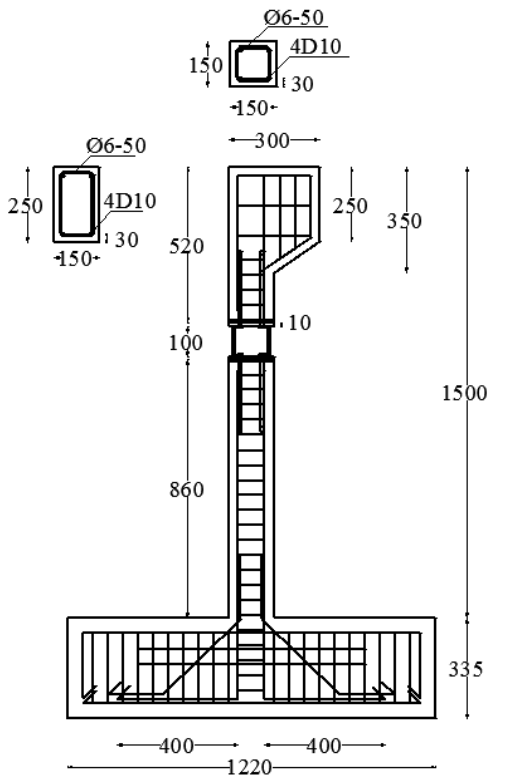

b) Kolom dengan sambungan profil

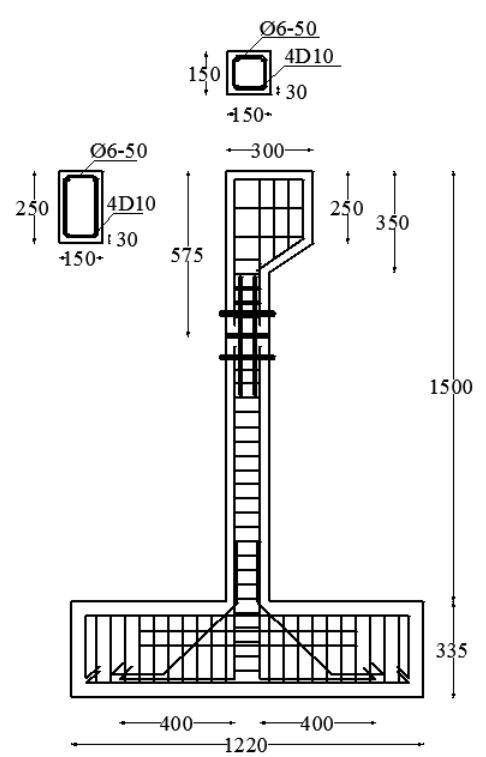

c) Kolom dengan sambungan plat

Gambar 3. Desain benda uji
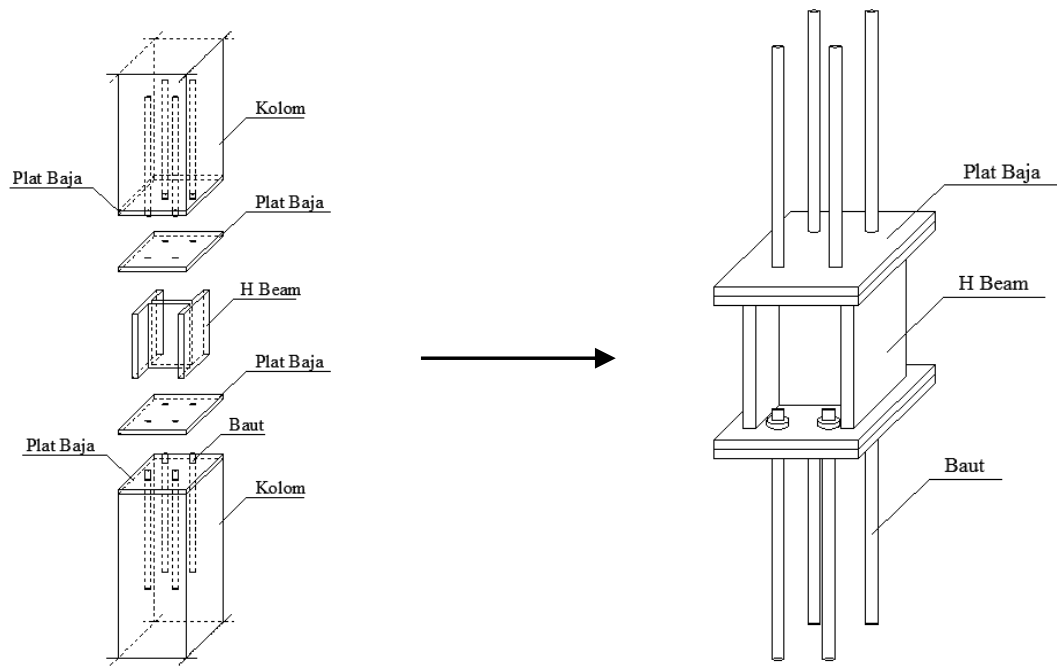

a) Profil
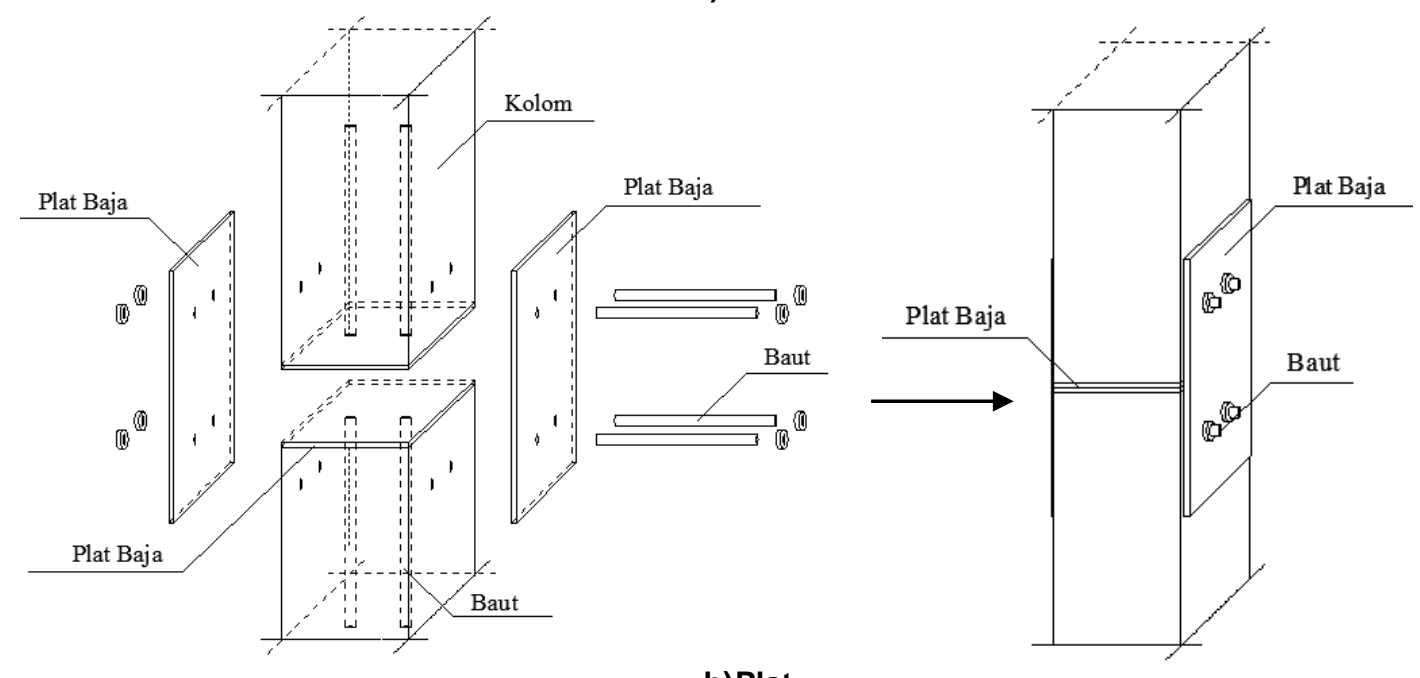

b)Plat

Gambar 4. Desain sambungan 
Tabel 1. Dimensi sambungan profil dan sambungan plat
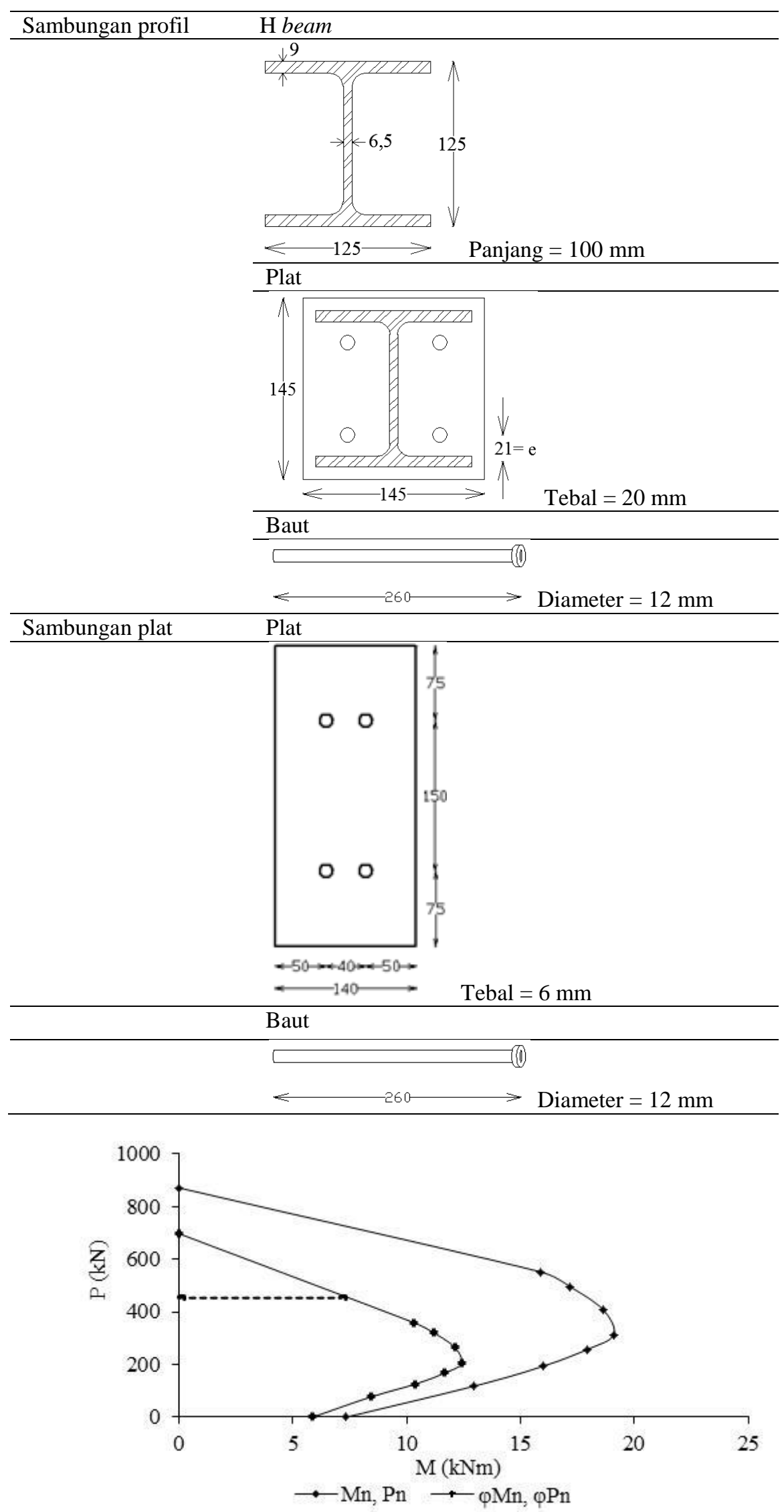

Gambar 5. Diagram interaksi kolom 
Kemampuan nominal kolom dilihat dari diagram interaksi P-M kolom seperti pada Gambar 5. Hasil analisis menunjukkan kolom tersebut dapat digunakan pada bangunan tempat tinggal atau ruko sederhana 3 lantai. Maksimal jarak antar kolom yang digunakan adalah $4 \mathrm{~m}$.

Eksentrisitas beban yang direncanakan adalah 0,067 m. Pada beban $200 \mathrm{kN}$ dan eksentrisitas $0,067 \mathrm{~m}$, momen yang terjadi adalah sebesar 13,4 $\mathrm{kNm}$. Kondisi ini terjadi di luar diagram interaksi kolom, sehingga kolom dengan eksentrisitas 0,067 m diperkirakan sudah runtuh pada beban $200 \mathrm{kN}$.

\section{Metode pengujian dan jumlah benda uji}

Kolom yang diuji sebanyak tiga buah, yaitu satu buah kolom tanpa sambungan, satu buah kolom dengan sambungan profil, dan satu buah kolom dengan sambungan plat. Total LVDT yang digunakan sebanyak 5 buah seperti yang ditampilkan pada set up pengujian Gambar 6 . Strain gauge beton diletakkan di tengah tinggi kolom atau sejauh $750 \mathrm{~mm}$ dari ujung atas kolom maupun ujung bawah kolom.

\section{Analisis numerik dengan metode elemen hingga}

Analisis struktur menggunakan metode elemen hingga dilakukan dengan bantuan software SAP
2000. Beton dimodelkan dengan elemen segiempat 2 dimensi. Lebar elemen disesuaikan dengan penulangan struktur. Modulus elastisitas yang digunakan adalah modulus elastisitas beton normal $4700 \cdot \sqrt{f_{c}^{\prime}}$ dengan kuat tekan beton ( $\mathrm{f}_{\mathrm{c}}$ ) didapat dari hasil pengujian silinder. Angka poisson ratio $(\mu)$ beton yang digunakan adalah 0,2 . Analisis metode elemen hingga ini dilakukan untuk mengetahui pola dan distribusi tegangan yang terjadi pada kolom uji saat pembebanan.

Baja tulangan dimodelkan dengan elemen frame (batang) yang menempel sempurna pada elemen beton. Slip tulangan dan beton tidak dimodelkan dalama analisis ini. Modulus elastisitas baja adalah 200.000 MPa dengan poisson ratio (u) 0,3. Nilai tegangan leleh $\left(\mathrm{F}_{\mathrm{y}}\right)$ dan tegangan tarik batas $\left(\mathrm{F}_{\mathrm{u}}\right)$ didapat dari hasil pengujian kuat tarik baja.

Dimensi tulangan sengkang, tulangan utama, baut, plat, dan $\mathrm{H}$ beam yang digunakan disesuaikan dengan dimensi yang digunakan pada benda uji kolom. Propertis tulangan dan baut didefinisikan menggunakan frame sections, sedangkan propertis beton, $\mathrm{H}$ beam, dan plat didefinisikan menggunakan area sections dengan tipe planestress. Dimensi elemen beton, $\mathrm{H}$ beam, dan plat arah tebal kolom didefinisikan saat mendefinisikan propertis elemen.

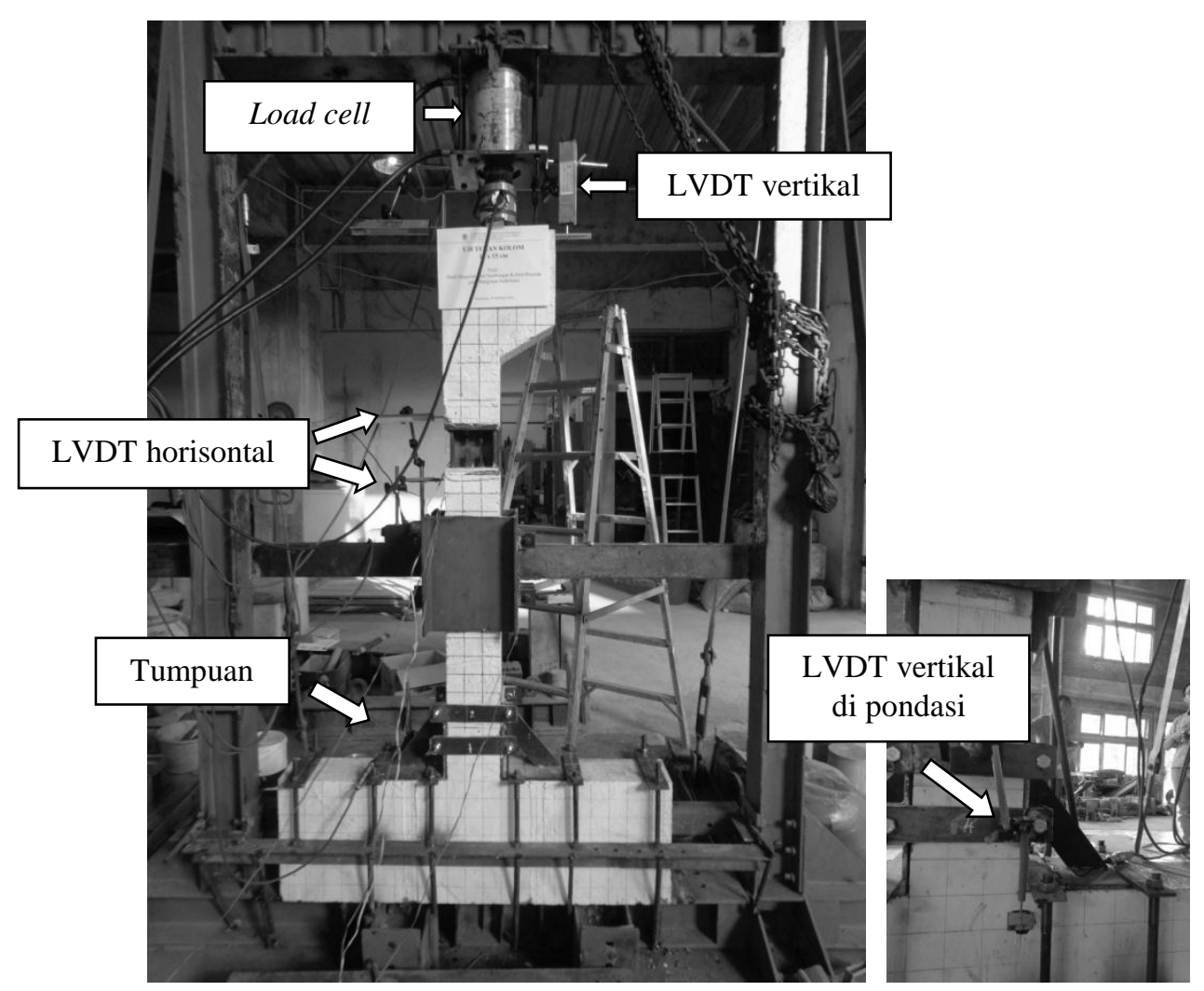

Gambar 6. Set up pengujian tekan kolom 
Beban yang digunakan hanya beban mati atau berat sendiri kolom dan beban luar yang sudah direncanakan membebani kolom. Kolom dibebani secara aksial dan momen lentur satu arah dengan eksentrisitas $67 \mathrm{~mm}$. Beban luar yang membebani kolom berupa beban garis dengan lokasi di atas kolom. Tumpuan yang digunakan berupa tumpuan jepit sesuai dengan jenis tumpuan yang digunakan saat pengujian. Pada lokasi beban diberikan spring untuk memodelkan tahanan yang terjadi di lokasi load cell akibat adanya load cell tersebut.

Software SAP 2000 hanya dapat menghasilkan output dengan perilaku linier. Beton pada umunya untuk tujuan praktis dapat dikatakan berperilaku linier saat kekuatannya mencapai $40 \%$ f'c atau sebelum terjadi keretakan pada beton. Oleh karena itu, analisis menggunakan software SAP 2000 untuk kolom tanpa sambungan hanya dilakukan hingga beban retak kolom.

\section{Analisis Hasil dan Pembahasan}

\section{Pengujian kuat tarik baja}

Pengujian kuat tarik baja dilakukan untuk mengetahui mutu dari baja yang digunakan dalam penelitian. Baja yang diuji tarik adalah baja tulangan, $\mathrm{H}$ beam yang digunakan pada sambungan, plat, dan baut. Pengujian ini dilakukan di Laboratorium Bahan dan Konstruksi Teknik Sipil Universitas Diponegoro. Hasil pengujian kuat tarik baja berupa tegangan leleh $\left(\mathrm{F}_{\mathrm{y}}\right)$ dan tegangan ultimit $\left(\mathrm{F}_{\mathrm{u}}\right)$ dapat dilihat pada Tabel 2 .
Tabel 2. Tegangan leleh (Fy) dan tegangan ultimit (Fu) yang digunakan

\begin{tabular}{llll}
\hline No & \multicolumn{1}{c}{ Sample baja } & $\begin{array}{c}\mathbf{F}_{\mathbf{y}} \\
(\mathbf{M P a})\end{array}$ & $\begin{array}{c}\mathbf{F}_{\mathbf{u}} \\
(\mathbf{M P a})\end{array}$ \\
\hline 1 & Tulangan $\phi 6$ & 348,1849 & 455,2877 \\
2 & Tulangan D10 & 381,0682 & 528,9593 \\
3 & Baut D12 & 338,2043 & 428,8342 \\
4 & H beam badan & 351,9669 & 483,0918 \\
5 & H beam sayap & 422,8571 & 548,5714 \\
6 & Plat tebal 10 mm & 349,4365 & 464,3265 \\
7 & Plat tebal 6 mm & 290,4873 & 427,6769 \\
\hline
\end{tabular}

\section{Pengujian kuat tekan silinder beton}

Pengujian kuat tekan silinder beton dilakukan untuk mengetahui mutu beton yang digunakan dalam penelitian. Silinder beton diuji tekan pada umur 15 hari dan pada saat pengujian. Silinder beton yang diuji adalah silinder beton dengan diameter $15 \mathrm{~cm}$ dan tinggi $30 \mathrm{~cm}$. Hasil pengujian kuat tekan silinder beton dapat dilihat pada Tabel 3. Usia 91 dan 121 hari adalah usia beton saat dilakukan pengujian struktur.

\section{Kemampuan beton menahan beban desain}

Hasil pengujian menunjukkan bahwa kolom belum mengalami keretakan saat dibebani sampai dengan beban desainnya. Retak pada pengujian kolom tanpa sambungan mulai terlihat ketika pembacaan beban mencapai $130 \mathrm{kN}$, sedangkan kolom dengan sambungan profil mengalami retak pada beban 180 $\mathrm{kN}$, dan kolom dengan sambungan plat retak pada beban $118 \mathrm{kN}$. Retak awal pada ketiga kolom uji teradapat di daerah tarik, kemudian merambat menuju garis netral. Pola retak kolom pada daerah tarik adalah seperti pada Gambar 7.

Tabel 3. Hasil pengujian kuat tekan silinder beton

\begin{tabular}{|c|c|c|c|c|c|c|c|}
\hline No & $\begin{array}{c}\text { Kode } \\
\text { benda } \\
\text { uji }\end{array}$ & $\begin{array}{c}\text { Tanggal } \\
\text { pengujian }\end{array}$ & $\begin{array}{l}\text { Umur } \\
\text { (hari) }\end{array}$ & $\begin{array}{c}\text { Gaya } \\
\text { tekan } \\
\text { (ton) }\end{array}$ & $\begin{array}{c}\text { Kokoh } \\
\text { tekan } \\
\left(\mathrm{kg} / \mathrm{cm}^{2}\right)\end{array}$ & $\begin{array}{c}\text { Perkiraan kokoh } \\
\text { silinder } 28 \text { hari } \\
\left(\mathrm{kg} / \mathrm{cm}^{2}\right)\end{array}$ & $\begin{array}{c}\text { Kuat tekan saat } \\
\text { pengujian } \\
\left(\mathrm{kg} / \mathrm{cm}^{2}\right)\end{array}$ \\
\hline 1 & \multirow{9}{*}{$\mathrm{K} 350$} & 07/08/2014 & 15 & 50 & 282,83 & 317,78 & \multirow{3}{*}{271,52} \\
\hline 2 & & 07/08/2014 & 15 & 47 & 265,86 & 298,72 & \\
\hline 3 & & $07 / 08 / 2014$ & 15 & 47 & 265,86 & 298,72 & \\
\hline 4 & & $22 / 10 / 2014$ & 91 & 71 & 401,62 & 334,68 & \multirow{3}{*}{398,79} \\
\hline 5 & & $22 / 10 / 2014$ & 91 & 70 & 395,96 & 329,97 & \\
\hline 6 & & $22 / 10 / 2014$ & 91 & 70 & 395,96 & 329,97 & \\
\hline 7 & & $21 / 11 / 2014$ & 121 & 80 & 452,53 & 377,10 & \multirow{3}{*}{458,18} \\
\hline 8 & & $21 / 11 / 2014$ & 121 & 82 & 463,84 & 386,53 & \\
\hline 9 & & $21 / 11 / 2014$ & 121 & 81 & 458,18 & 381,82 & \\
\hline
\end{tabular}




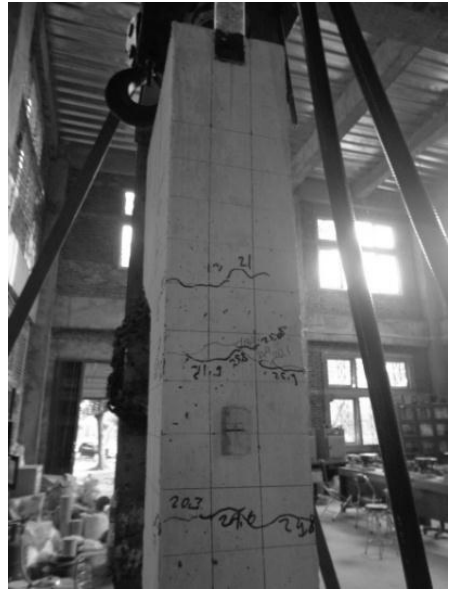

(a)

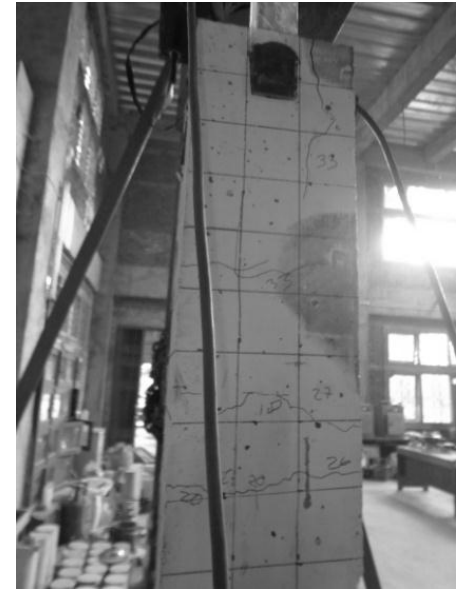

(b)

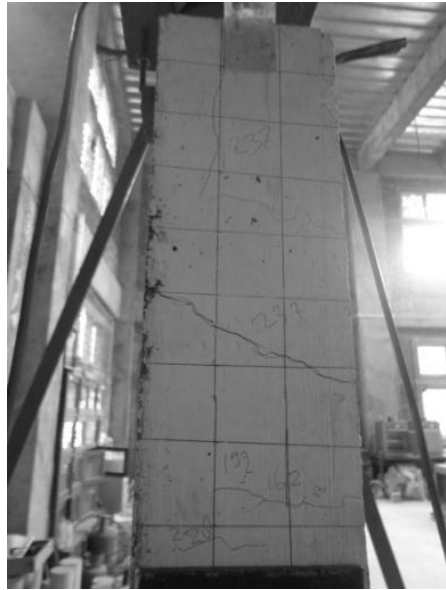

(c)

Gambar 7. Pola Retak Kolom Uji (a) Kolom Tanpa Sambungan (b) Kolom Sambungan Profil (c) Kolom Sambungan Plat

Analisis tegangan arah y hasil analisis FEM dilakukan menggunakan software SAP 2000. Analisis tegangan dilakukan menggunakan SAP 2000 karena tegangan retak yang terjadi kecil, sehingga dapat dianggap beton berperilaku linier. Pada saat beban retak, tegangan arah y sejarak 350 mm dari ujung atas kolom tanpa sambungan hasil analisis SAP 2000 menunjukkan angka 4,12 MPa, pada jarak $330 \mathrm{~mm}$ dari ujung atas kolom sambungan profil, tegangan arah y hasil analisis SAP 2000 menunjukkan angka 4,07 $\mathrm{MPa}$, sedangkan tegangan arah y hasil analisis SAP 2000 pada beban $118 \mathrm{kN}$ atau saat kolom eksperimen mulai mengalami keretakan adalah sebesar 4,71 $\mathrm{MPa}$. Tegangan ini ditinjau pada lokasi munculnya retak lentur di daerah tarik yaitu $380 \mathrm{~mm}$ dari ujung atas kolom.

\section{Pengujian hingga keruntuhan benda uji}

Regangan yang terjadi pada beton saat pengujian dapat diketahui dengan cara memasang strain gauge beton pada lokasi tengah tinggi kolom atau sejauh $750 \mathrm{~mm}$ dari ujung atas kolom maupun ujung bawah kolom. Hubungan beban regangan beton pada tengah bentang pada ketiga benda uji kolom dapat dilihat pada Gambar 8.

Regangan beton pada ketiga benda uji belum mencapai regangan runtuh tekan beton 0,003 . Hal ini menunjukkan bahwa beton belum mengalami keruntuhan pada posisi tengah tinggi kolom. Hasil ini sesuai dengan saat pengujian dilakukan. Pada posisi tengah tinggi kolom, posisi tengah bentang belum mengalami kerusakan. Beban maksimum yang mampu dipikul ketiga benda uji kolom dan regangan tekan beton pada tengah tinggi kolom secara ringkas disajikan pada Tabel 4.

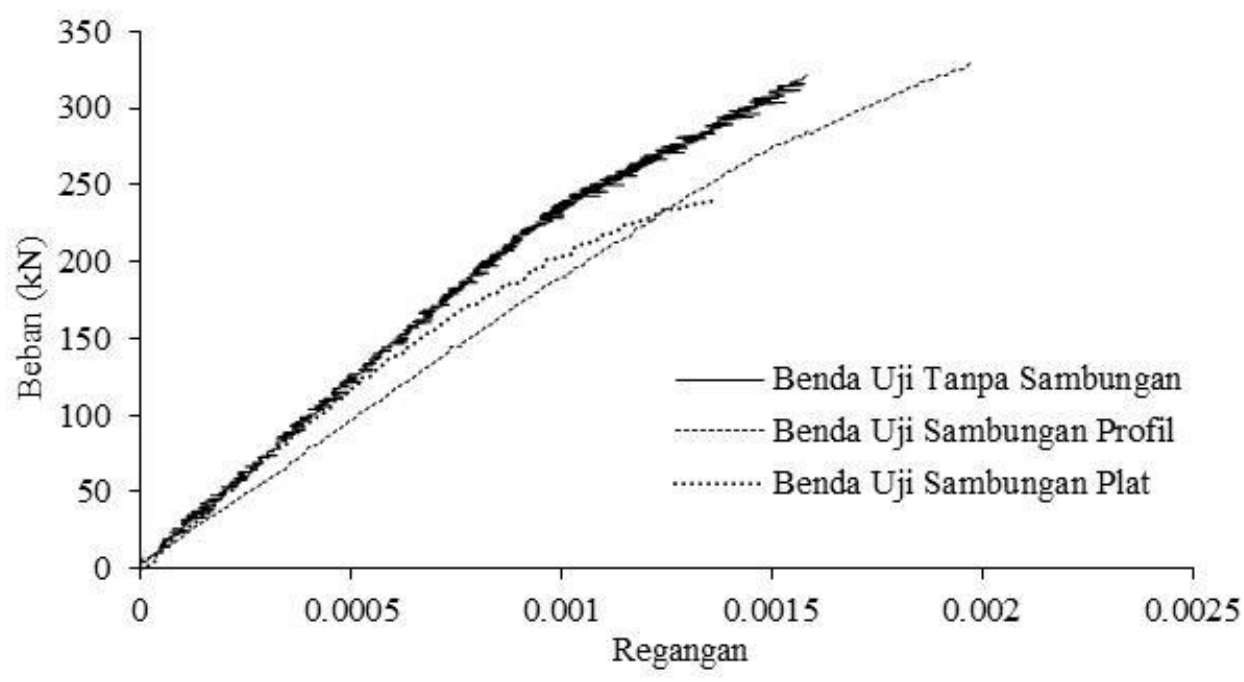

Gambar 8. Hubungan beban regangan tekan beton pada ketiga benda uji kolom 
Tabel 4. Beban maksimum dan regangan tekan beton pada ketiga benda uji kolom

\begin{tabular}{lrr}
\hline & Beban Maksimum $(\mathbf{k N})$ & Regangan Tekan Beton \\
\hline Kolom tanpa sambungan & 321,570 & 0,001583 \\
Kolom sambungan profil & 331,938 & 0,001972 \\
Kolom sambungan plat & 239,760 & 0,001363 \\
\hline
\end{tabular}

Ketiga kolom uji mengalami retak di bidang geser atau di corbel sebelum mencapai runtuh, selain retak di daerah tarik. Kekuatan geser pada corbel perlu diperhitungkan kembali karena terjadi retak pada bidang geser kantilever. Hasil analisis menunjukkan kekuatan geser dari tulangan dan beton pada daerah corbel ternyata lebih kecil dari gaya geser yang terjadi. Namun demikian, kekuatan geser corbel dari pengujian lebih besar dari perhitungan kapasitas geser berdasarkan peraturan (SNI 03-2847-2002 Pasal 13.9).

\section{Kesimpulan}

Dari hasil analisis dan pembahasan diatas dapat disimpulkan sebagai berikut:

1. Kolom DfD yang diuji dapat diaplikasikan pada bangunan tempat tinggal atau ruko sederhana dua atau tiga lantai dengan jarak antar kolom maksimum $4 \mathrm{~m}$.

2. Sampai dengan kegagalan geser yang terjadi di corbel, kolom dengan sambungan profil mempunyai kemampuan menahan beban yang lebih baik. Hal ini ditinjau dari grafik beban dan regangan yang lebih stabil (linier sampai dengan beban $250 \mathrm{kN}$, seperti pada Gambar 9).

3. Kegagalan geser di corbel terjadi karena gaya geser yang terjadi lebih besar dari kuat geser korbel. Kuat geser corbel yang disarankan oleh peraturan (SNI 03-2847-2002 Pasal 13.9) cukup aman digunakan karena masih lebih kecil dari kuat geser pengujian.

\section{Daftar Pustaka}

ASTM C 39., 2002. Test Method for Compressive Strength of Cylindrical Concrete Spesimens. Annual Books of ASTM Standards, USA.

Imran, I, dkk., 2009. Studi Eksperimental Sambungan Kolom-Kolom Pada Sistem Beton
Pracetak dengan Menggunakan Sleeves, Seminar dan Pameran HAKI.

Indarwanto, Muji, 2012. Precast Concrete, Pusat Pengembangan Bahan Ajar, Universitas Mercu Buana, Jakarta.

Lehmann, S., 2013. Low Carbon Construction Systems Using Prefabricated Engineered Solid Wood Panles For Urban Infill To Significanctly Reduce Greenhouse Gas Emissions, Sustainable Cities and Society 6 (2013), Pp. 57-67.

Mulyono, T., 2006. Teknologi Beton, Penerbit Andi, Yogyakarta.

Park, R., Paulay, T., 1975. Reinforced Concrete Structure, John Willey \& Sons, New York.

PBI., 1989. Standar Uji Bahan Bangunan Indonesia, Institut Teknologi Bandung, Bandung.

SNI 03-2847-2002, 2002. Tata Cara Perhitungan Struktur Beton Untuk Bangunan Gedung, Badan Standarisasi Nasional, Bandung.

Thormark, C., 2001. Recycling Potential and Design for Disassembly in Buildings, Lund University, Swedia.

Tjahjono, E. dan Heru Purnomo, 2004. Pengaruh Penempatan Penyambungan Pada Perilaku Rangkaian Balok-Kolom Beton Pracetak Bagian Sisi Luar, Makara, Teknologi, Vol. 8, No.3. Universitas Indonesia, Depok.

Wahyudi, H. \& Hery Dwi Hanggoro, 2010. Perencanaan Struktur Gedung BPS Provinsi Jawa Tengah Menggunakan Beton Pracetak, Thesis. Universitas Diponegoro, Semarang.

Wibowo, L. S. B., dkk., 2011. Studi Perilaku Sambungan Pracetak untuk Rumah Sederhana Tahan Gempa Akibat Beban Siklik, Tesis, Institut Teknologi Sepuluh Nopember, Surabaya. 